\title{
COMPLEMENT FACTOR H Y403H POLYMORPHISM IN THE TURKISH POPULATION
}

\author{
Yunus Arikan $\mathrm{Y}^{\#}$, Türker Bilgen $\mathrm{T}^{\#}$, Ibrahim Keser I ${ }^{1, *}$
}

\begin{abstract}
*Corresponding Author: Ibrahim Keser, Department of Medical Biology and Genetics, Faculty of Medicine, Akdeniz University, TR-07059, Antalya, Turkey; Tel.:+90-242-249-6973; Fax:+90242-227-4495; E-mail: keser@akdeniz.edu.tr
\end{abstract}

\begin{abstract}
Complement factor $\mathrm{H}(\mathrm{CFH})$ is an important regulator protein of the alternative pathway of the complement system. The $\mathrm{CFH}$ mutations and polymorphisms in $\mathrm{CFH}$ have been associated with diseases of the kidney and eye. We investigated the allelic frequency of the most common $\mathrm{CFH}$ polymorphism, c. $1277 \mathrm{~T}>\mathrm{C}(\mathrm{Y} 402 \mathrm{H})$, in 100 healthy Turkish volunteers from the Antalya Province by direct sequencing of the corresponding genomic region. We found a frequency of $0.65 \%$ for the $\mathrm{T}$ and $0.35 \%$ for the $\mathrm{C}$ alleles. The frequency of the TT, CT and CC genotypes was $0.40,0.49$ and $0.11 \%$ respectively. Thus, the disease-related $\mathrm{C}$ allele has a frequency in Turkey similar to that of Caucasian populations.
\end{abstract}

Key words: Complement factor $\mathrm{H}(\mathrm{CFH}), \mathrm{c} .1277$ $\mathrm{T}>\mathrm{C}$, Polymorphism, Y402H.

Department of Medical Biology and Genetics, Faculty of Medicine, Akdeniz University, TR-07059, Antalya, Turkey

\# These two authors contributed equally to this study.

\section{INTRODUCTION}

Complement factor $\mathrm{H}(\mathrm{CFH})$ is an important member of the regulator of complement activation protein family of innate immunity. The $\mathrm{CFH}$, a plasma glycoprotein or attached to outer cell membrane, restricts the activation of complement on the host cell membrane and protects tissues from damage produced by complement activation $[1,2]$.

The $\mathrm{CFH}$ gene is located on chromosome 1q32 and encodes 23 exons for a $155 \mathrm{kDa}$ glycoprotein [24]. More than 550 single nucleotide polymorphisms (SNPs) of the gene have been discovered (www. ncbi.nih.gov/SNP). The c.1277 $\mathrm{T}>\mathrm{C}(\mathrm{Y} 402 \mathrm{H})$ is a well known polymorphism that leads to substitution of tyrosine by histidine at codon 402. This polymorphism is located on the short consensus repeat 7 (SCR-7) domain of the $C F H$ protein that binds the $\mathrm{C}$-reactive protein (CRP), sialic acid and heparin [2,5-7].

The $C F H$ mutations have been associated with adult or atypic hemolytic uremic syndrome (aHUS), HUS, membrano proliferative glomerulo nephritis 2 (MPGN2), age-related macular degeneration (AMD) and basal laminar drusen [8-16] Although the c.1277 $\mathrm{T}>\mathrm{C}$ variant is less common in renal diseases, it is strongly associated with AMD $[17,18]$. We have determined the frequency of the c.1277 $\mathrm{T}>\mathrm{C}$ polymorphism of the $C F H$ gene in a Turkish population from southwest Turkey. 


\section{MATERIALS AND METHODS}

We examined 54 females and 46 males (aged 17 to51 years) from the university staff, who declared that they had no health problems. They were all from Antalya Province in Turkey and all gave their informed consent.

Genomic DNA was isolated from whole peripheral blood samples by the classic saltingout procedure [19]. The region which includes the c. $1277 \mathrm{~T}>\mathrm{C}$ variant in the $C F H$ gene was amplified using polymerase chain reaction (PCR) by forward primer 5'-CTT TGT TAG TAA CTT TAG TTC GTC TTC AG-3' and reverse primer 5'-CAA GGT GAC ATA ACA TTT TGC C-3'. Approximately 100 ng of genomic DNA, measured by NanoDrop 1000 (Thermo Scientific, Wilmington, DE, USA), was used in $25 \mu \mathrm{L}$ reaction volumes. The PCR mixture contained: $1.25 \mathrm{U}$ Taq polymerase (GoTaq; Promega, Madison, WI, USA), 10X buffer ( $\mathrm{pH}$ 8.8 with ammonium sulfate; Fermentas, Vilnius, Lithuania), $1.5 \mathrm{mM} \mathrm{MgCl}$ (Fermentas), 5 pmol of each primer and $200 \mathrm{mM}$ of each of the four dNTPs. The PCR program consisted of 40 cycles of initial denaturation at $93^{\circ} \mathrm{C}$ for 150 seconds, 36 cycles of 30 seconds at $93^{\circ} \mathrm{C}, 45$ seconds at $58^{\circ} \mathrm{C}, 60$ seconds at $72^{\circ} \mathrm{C}$, and final extension at $72^{\circ} \mathrm{C}$ for $5 \mathrm{~min}$. The $443 \mathrm{bp}$ PCR products were electrophoresed on $2.5 \%$ agarose gel containing ethidium bromide, and then visualized under UV light using imaging system (SynGene InGenius, Cambridge, Cambridgeshire, UK).

The PCR products were purified by PureLink ${ }^{\mathrm{TM}}$ PCR Purification Kit (Invitrogene, Carlsbad, CA, USA). Sequencing was done using the BigDye Terminator v3.1 Cycle Sequencing kit and an ABI PRISM $^{\mathrm{TM}} 3130 \times 1$ Genetic Analyzer (Applied Biosystems, Foster City, CA, USA). The allele and genotype frequencies were calculated using the allele counting method.

\section{RESULTS}

Direct sequencing of the $443 \mathrm{bp}$ PCR products showed no genomic alteration other than c. 1277 $\mathrm{T}>\mathrm{C}$. The frequency of the $\mathrm{T}$ and $\mathrm{C}$ alleles was 0.65 and $0.35 \%$, respectively (Table 1 ). The TT, CT and $\mathrm{CC}$ genotypes had a frequency of $0.40,0.49$ and $0.11 \%$, respectively. Representative samples of the sequences of each genotype are shown in Figure 1.

\section{DISCUSSION}

The $C F H$-mediated inactivation of the alternative pathway protects the host cell membranes from excessive complement system activation. The $\mathrm{Y} 402 \mathrm{H}$ substitution interferes with the binding ability of the SCR7 domain for

Table 1. Frequency of the $C F H$ gene c. $1277 \mathrm{~T}>\mathrm{C}$ alleles in different populations.

\begin{tabular}{|l|c|c|c|}
\hline Population & Healthy Controls (n) & C Allele Frequency (\%) & References \\
\hline American (Icelandic) & 1,265 & 0.39 & 26 \\
\hline American & 108 & 0.31 & 27 \\
\hline American & 190 & 0.36 & 9 \\
\hline American $^{\mathrm{a}}$ & 275 & 0.34 & 22 \\
\hline American $^{\mathrm{a}}$ & 48 & 0.38 & 12 \\
\hline European American $^{\text {German }}$ & 403 & 0.34 & 15 \\
\hline French & 612 & 0.38 & 16 \\
\hline Greek & 91 & 0.30 & 28 \\
\hline Japanese & 115 & 0.37 & 29 \\
\hline Turks & 107 & 0.11 & This study \\
\hline
\end{tabular}

${ }^{a}$ Control groups were specifically defined as non Hispanic Whites in these two studies. 

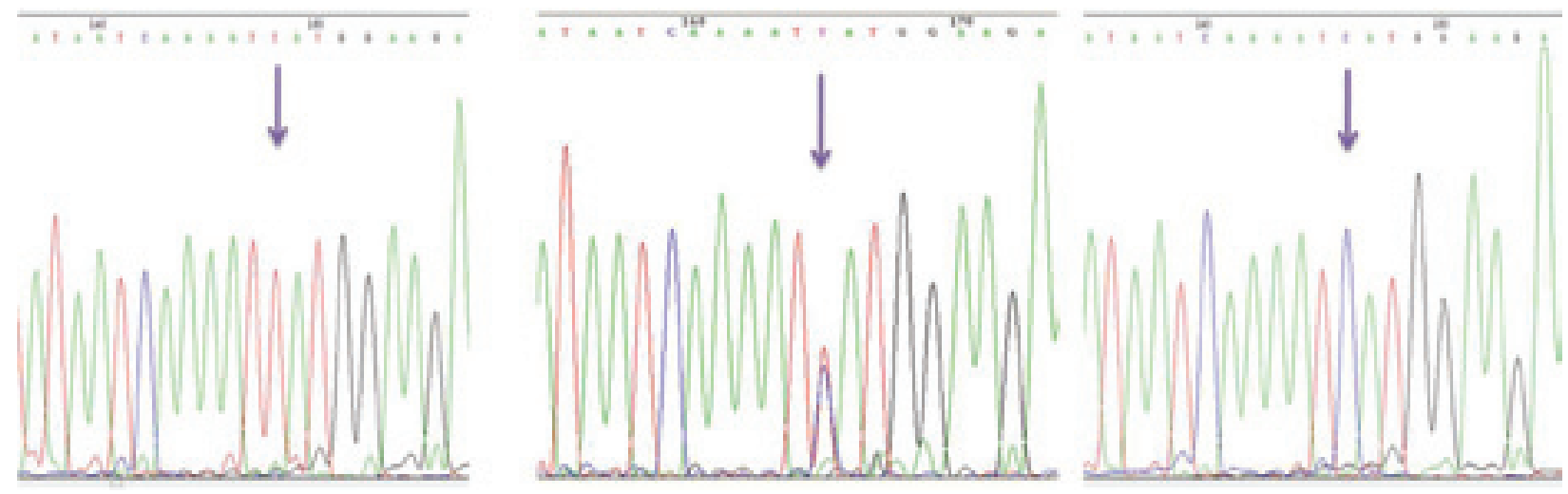

Figure 1. The c.1277 $\mathrm{T}>\mathrm{C}$ substitution of the $C F H$ gene. The arrows indicate the substitution positions and show the TT, TC and CC genotypes.

poly-anionic molecules such as heparin and CRP, which are biological markers of inflammation $[6,20]$. As a consequence, this variant leads to cell loss and increased damage of target tissues. The CFH mutations and variants have been associated with renal and ocular conditions like MPGN2, aHUS, basal laminar drusen, and AMD. Sometimes patients may have more than one of these conditions, suggesting common mechanisms in their pathogenesis [1]. However, there is no straightforward genotype-phenotype correlation between the $C F H$ variants and disease [1]. It has been reported that the $\mathrm{C}$ allele for the $\mathrm{CFH}$ c.1277 $\mathrm{T}>\mathrm{C}$ polymorphism increases the odds ratio of AMD up to 6-fold in different populations except the Japanese [21-23]. An 8-fold increased risk of developing AMD has been reported for the CC genotype with a positive family history of AMD [16]. Ethnic differences in disease-susceptible genomic alterations have also been shown for the $\mathrm{CFH}$-related phenotypes [24,25]. While the $\mathrm{C}$ allele frequency varies between 0.30 and $0.39 \%$ in different Caucasian populations, its frequency is $0.11 \%$ for Japanese people [24,29]. We found the $\mathrm{C}$ allele frequency to be $0.35 \%$ in our Turkish population (Table 1). This $\mathrm{C}$ allele frequency makes it important, especially for AMD in Turkey. Our experimental results revealed no other SNPs in the region comprising the SCR-7 domain of the CFH gene. This may imply that the SCR-7 domain is a conserved and func-tionally-important region of the $\mathrm{CFH}$ gene.

\section{ACKNOWLEDGMENTS}

This study was supported by Akdeniz University Scientific Projects Management Units, Antalya, Turkey.

\section{REFERENCES}

1. Boon CJ, van de Kar NC, Klevering BJ, Keunen JE, Cremers FP, Klaver CC, Hoyng CB, Daha MR, den Hollander AI. The spectrum of phenotypes caused by variants in the CFH gene. Mol Immunol. 2009; 46(8-9): 1573-1594.

2. Rodriguez de Cordoba S, Esparza-Gordillo J, Goicoechea de Jorge E, Lopez-Trascasa M, Sanchez-Corral P. The human complement factor $\mathrm{H}$ : functional roles, genetic variations and disease associations. Mol Immunol. 2004; 41(4): 355-367.

3. Male DA, Ormsby RJ, Ranganathan S, Giannakis E, Gordon DL. Complement factor H: sequence analysis of $221 \mathrm{~kb}$ of human genomic DNA containing the entire FH, FHR-1 and FHR-3 genes. Mol Immunol. 2000; 37(1-2): 41-52.

4. Ripoche J, Day AJ, Harris TJ, Sim RB. The complete amino acid sequence of human complement factor H. Biochem J. 1988; 249(2): 593-602.

5. Blackmore TK, Sadlon TA, Ward HM, Lublin DM, Gordon DL. Identification of a heparin binding domain in the seventh short consensus repeat of complement factor H. J Immunol. 1996; 157(12): $5422-5427$. 
6. Pangburn MK, Atkinson MA, Meri S. Localization of the heparin-binding site on complement factor H. J Biol Chem. 1991; 266(25): 16847-16853.

7. Ram S, McQuillen DP, Gulati S, Elkins C, Pangburn MK, Rice PA. Binding of complement factor $\mathrm{H}$ to loop 5 of porin protein 1a: a molecular mechanism of serum resistance of nonsialylated neisseria gonorrhoeae. J Exp Med. 1998; 188(4):671-680.

8. Zipfel PF, Heinen S, Jozsi M, Skerka C. Complement and diseases: defective alternative pathway control results in kidney and eye diseases. Mol Immunol. 2006; 43(1-2): 97-106.

9. Edwards AO, Ritter R, 3rd, Abel KJ, Manning A, Panhuysen C, Farrer LA. Complement factor $\mathrm{H}$ polymorphism and age-related macular degeneration. Science. 2005; 308(5720): 421-424.

10. Hageman GS, Anderson DH, Johnson LV, Hancox LS, Taiber AJ, Hardisty LI, Hageman JL, Stockman HA, Borchardt JD, Gehrs KM, Smith RJ, Silvestri G, Russell SR, Klaver CC, Barbazetto I, Chang S, Yannuzzi LA, Barile GR, Merriam JC, Smith RT, Olsh AK, Bergeron J, Zernant J, Merriam JE, Gold B, Dean M, Allikmets R. A common haplotype in the complement regulatory gene factor $\mathrm{H}$ (HF1/CFH) predisposes individuals to agerelated macular degeneration. Proc Natl Acad Sci USA. 2005; 102(20): 7227-7232.

11. Haines JL, Hauser MA, Schmidt S, Scott WK, Olson LM, Gallins P, Spencer KL, Kwan SY, Noureddine M, Gilbert JR, Schnetz-Boutaud N, Agarwal A, Postel EA, Pericak-Vance MA. Complement factor $\mathrm{H}$ variant increases the risk of age-related macular degeneration. Science. 2005; 308(5720): 419-421.

12. Klein RJ, Zeiss C, Chew EY, Tsai JY, Sackler RS, Haynes C, Henning AK, SanGiovanni JP, Mane SM, Mayne ST, Bracken MB, Ferris FL, Ott J, Barnstable C, Hoh J. Complement factor H polymorphism in age-related macular degeneration. Science. 2005; 308(5720): 385-389.

13. Seitsonen S, Jarvela I, Meri S, Tommila P, Ranta P, Immonen I. Complement factor H Y402H polymorphism and characteristics of exudative age-related macular degeneration lesions. Acta Ophthalmol. 2008; 86(4): 390-394.

14. Xu Y, Guan N, Xu J, Yang X, Ma K, Zhou H, Zhang F, Snellingen T, Jiao Y, Liu X, Wang N,
Liu N. Association of CFH, loc387715, and HTRA1 polymorphisms with exudative age-related macular degeneration in a northern chinese population. Mol Vis. 2008; 28(14): 1373-1381.

15. Rivera A, Fisher SA, Fritsche LG, Keilhauer CN, Lichtner P, Meitinger T, Weber BH. Hypothetical loc387715 is a second major susceptibility gene for age-related macular degeneration, contributing independently of complement factor $\mathrm{H}$ to disease risk. Hum Mol Genet. 2005; 14(21): 3227-3236.

16. Souied EH, Leveziel N, Richard F, DragonDurey MA, Coscas G, Soubrane G, Benlian P, Fremeaux-Bacchi V. Y402h complement factor $\mathrm{H}$ polymorphism associated with exudative age-related macular degeneration in the French population. Mol Vis. 2005; 19(11): 1135-1140.

17. Saunders RE, Goodship TH, Zipfel PF, Perkins SJ. An interactive web database of factor $\mathrm{H}$-associated hemolytic uremic syndrome mutations: insights into the structural consequences of disease-associated mutations. Hum Mutat. 2006; 27(1): 21-30.

18. Johnson PT, Betts KE, Radeke MJ, Hageman GS, Anderson DH, Johnson LV. Individuals homozygous for the age-related macular degeneration risk-conferring variant of complement factor $\mathrm{H}$ have elevated levels of CRP in the choroid. Proc Natl Acad Sci USA. 2006; 103(46): 17456-17461.

19. Miller SA, Dykes DD, Polesky HF. A simple salting out procedure for extracting DNA from human nucleated cells. Nucleic Acids Res. 1988; 16(3): 1215.

20. Blackmore TK, Hellwage J, Sadlon TA, Higgs N, Zipfel PF, Ward HM, Gordon DL. Identification of the second heparin-binding domain in human complement factor H. J Immunol. 1998; 160(7): 3342-3348.

21. Gotoh N, Yamada R, Hiratani H, Renault V, Kuroiwa S, Monet M, Toyoda S, Chida S, Mandai M, Otani A, Yoshimura N, Matsuda F. No association between complement factor $\mathrm{H}$ gene polymorphism and exudative age-related macular degeneration in Japanese. Hum Genet. 2006; 120(1): 139-143.

22. Zareparsi S, Branham KE, Li M, Shah S, Klein RJ, Ott J, Hoh J, Abecasis GR, Swaroop A. Strong association of the $\mathrm{Y} 402 \mathrm{H}$ variant in complement factor $\mathrm{H}$ at $1 \mathrm{q} 32$ with susceptibility to age-related macular degeneration. Am J Hum Genet. 2005; 77(1): 149-153. 
23. Caprioli J, Castelletti F, Bucchioni S, Bettinaglio P, Bresin E, Pianetti G, Gamba S, Brioschi S, Daina E, Remuzzi G, Noris M. Complement factor $\mathrm{H}$ mutations and gene polymorphisms in haemolytic uraemic syndrome: the C-257T, the A2089G and the G2881T polymorphisms are strongly associated with the disease. Hum Mol Genet. 2003; 12(24): 3385-3395.

24. Mori M, Yamada R, Kobayashi K, Kawaida $\mathrm{R}$, Yamamoto $\mathrm{K}$. Ethnic differences in allele frequency of autoimmune-disease-associated SNPs. J Hum Genet. 2005; 50(5): 264-266.

25. Tsai HJ, Sun G, Weeks DE, Kaushal R, Wolujewicz M, McGarvey ST, Tufa J, Viali S, Deka $\mathrm{R}$. Type 2 diabetes and three calpain-10 gene polymorphisms in Samoans: no evidence of association. Am J Hum Genet. 2001; 69(6): 1236-1244.

26. Magnusson KP, Duan S, Sigurdsson H, Petursson H, Yang Z, Zhao Y, Bernstein PS, Ge J, Jonasson F, Stefansson E, Helgadottir G, Zabriskie NA, Jonsson T, Bjornsson A, Thorlacius T, Jonsson
PV, Thorleifsson G, Kong A, Stefansson H, Zhang K, Stefansson K, Gulcher JR. CFH Y402H confers similar risk of soft drusen and both forms of advanced amd. PLoS Med. 2006; 3(1): e5.

27. Conley YP, Thalamuthu A, Jakobsdottir J, Weeks DE, Mah T, Ferrell RE, Gorin MB. Candidate gene analysis suggests a role for fatty acid biosynthesis and regulation of the complement system in the etiology of age-related maculopathy. Hum Mol Genet. 2005; 14(14): 1991-2002.

28. Marioli DI, Pharmakakis N, Deli A, Havvas I, Zarkadis IK. Complement factor $\mathrm{H}$ and loc387715 gene polymorphisms in a Greek population with age-related macular degeneration. Graefes Arch Clin Exp Ophthalmol. 2009; 247(11): 1547-1553.

29. Uka J, Tamura H, Kobayashi T, Yamane K, Kawakami H, Minamoto A, Mishima HK. No association of complement factor $\mathrm{H}$ gene polymorphism and age-related macular degeneration in the Japanese population. Retina. 2006; 26(9): 985-987. 